\title{
UTILIZATION OF BANANA IN THE DEVELOPMENT OF NUTRIENT RICH
}

\section{BANANA BAR}

\author{
R. ARUNA ${ }^{1}$, K. VINAY PROMOD KUMAR ${ }^{2} \&$ K. SOWJANYA ${ }^{3}$ \\ ${ }^{1}$ Department of Food Chemistry and Nutrition, CFST, ANGRAU, Andhra Pradesh, India \\ ${ }^{2,3}$ Department of Food Science and Technology, CFST, ANGRAU, Andhra Pradesh, India
}

\begin{abstract}
The fruit banana, is produced on a large scale in the country. Banana is consumed as fresh and also in processed forms such as figs, snack foods and chips. But being highly perishable in nature, there is a strong need to minimize the huge post harvest losses of this important fruit. Today, bananas and plantains are best known as a food crop, almost every part of the plant can be used in one way or another, this may explain, why in India the banana is popularly known as "kalpataru”, meaning "herb with all imaginable uses". Bananas also known as "The fruit eaten by wise men" is because, for it's both cheap and full of nutrients, are rich in fiber, vitamins and minerals. Research has proven that, just two bananas provide enough energy for a strenuous 90-minute workout. No wonder, the banana is the number one fruit with the World's leading athletes. In this regard, the pulp banana is used for preparation of banana bar. The pulp of banana with higher amount of water, and required amount of soluble fiber is selected. Musa Paradisica of Indian origin species is generally the wide distributed variety, used all over the country and it is used in the preparation of slab/bar. Finely grinded and sieved sugar, which has less granule size, is used in the preparation of slab/bar.
\end{abstract}

KEYWORDS: Kalpataru \& Musa Paradisica

Received: Aug 09, 2017; Accepted: Aug 29, 2017; Published: Sep 16, 2017; Paper Id.: IJASROCT201725

\section{INTRODUCTION}

India is the third largest producer of fruits \& vegetables, in the world. Fruits \& vegetables with their rich contents of minerals, vitamins, and dietary fiber $\&$ anti oxidants are the protective foods $\&$ considered as nature gifts for health $\&$ well being of humans. They are highly perishable in nature, due to high moisture content (70$95 \%$ ); soft texture etc bacterial rotting by microbial respiration, as well as physiological breakdown is seen. Moisture degradation in the quality of fruits \& vegetables also starts immediately after the harvest leading to drying \& shriveling. Fruits $\&$ vegetables absorb environment gasses, such as oxygen $\&$ produce carbon dioxide $\&$ ethylene. They also get infested easily with micro organisms like fungi, bacteria $\&$ insects affecting food safety. In villages where fruits \& vegetables are grown in plenty, facilities for processing are not in existence $\&$ lot of them are wasted. In the country, the whole food processing industry, is still has not grown big \& presently less than $4 \%$ of horticultural produce is being processed industrially (Golb, 2007).

Hence, these fruits \& vegetables are to be preserved \& protected, from deterioration in both quality \& quantity. Recent statistics showed that, nearly $50 \%$ of the losses also occur due to improper handling, inadequate infra structure facilities for processing, preservation, storage, distant markets, high cost \& inappropriate packaging, out dated technologies \& machinery. As a result the wastage, in monetary terms is to the tune of 
Rs.2500-30,000 crores (FAO, 2005).

Bananas also contain a rich supply of vitamin B6, providing 20\% of the Recommended Daily Allowance of B6 is significant in the synthesis of antibodies, in the immune system. It also helps in protein metabolism, red blood cell formation and functioning of the central nervous system. The vitamin $\mathrm{C}$ in bananas, helps your body to heal and defend against infections. Vitamin $\mathrm{C}$ also is valuable in the absorption of iron, synthesis of connective tissue, and blood formation. The good source of potassium from bananas is helpful, for your body to maintain fluid balance in blood and tissue cells. Because, bananas are sodium-free and very rich in potassium, they can be eaten as part of a diet, to reduce risk of high blood pressure. In the present study, various trails were conducted, to standardize the preparation of banana bar (Chad Hagy, 2007).

\section{MATERIALS AND METHODOLOGY}

All chemicals were purchased, from Qualigens Fine Chemicals (Mumbai, India) or Molychem India Pvt. Ltd. (Mumbai, India). Unless otherwise mentioned, all chemicals used were of analytical grade. In the present study, bananas were collected aseptically from local super markets, and used for standardization and development of banana bar.

\section{STANDARDIZATION OF PRODUCT}

Various trails were carried out to standardize the product. Based on the subjective evaluation, the trail which scored the maximum for all the sensory attributes and overall acceptability was selected, as the best standard sample and was chosen for product development further.

\section{SENSORY ANALYSIS}

The product developed in each trail was subjected to sensory evaluation with the panel members. Five point hedonic scales were chosen to test the acceptability, where the judges express their evaluation according to the scores given for each sensory attributes on the score card provided. Separate column was given to write the remarks, based on the results, modifications were made in the recipe and was presented again in the other trail.

\section{Standardization and Development of Banana Bar \\ Processing of Raw Materials}

The suitable variety of bananas is collected from the nearby market, just before processing. The bananas are hygienically peeled in the aseptic conditions.

Proper measures are to be taken to avoid damage, to the bananas and to prevent the browning reactions immediately. After peeling the bananas are immediately blanched, at a temperature of $85^{\circ} \mathrm{C}$, for about 5 minutes. Immediate blanching prevents the rapid enzymatic browning, and inactivates the polyphenoloxidase, which is responsible for the browning reactions. For blanching, we have to use clean and soft water for blanching.

Blanched slices are thoroughly mashed, in a mixer and strained to extract the pulp. Citric acid and KMS are added to the pulp, by dissolving in a table spoon of water. After the pulp is ready, suitable plates are selected and smeared with glycerin or butter. Usually, glycerin is preferable than butter, due to the occurrences of rancidity with the butter (Prasad, K. et al., 2002). After smearing, the pulp is spread uniformly in the plates. These are kept for drying, which is completed at about $55^{\circ} \mathrm{C}$ for about 10-12 hours. After drying the banana slabs, they are cut into good looking pieces and are wrapped in 
polythene covers and are stored in an air tight container (Lejju, 2007).

\section{Standardization of the Ingredients}

Standardization of different ingredients is carried out in different trails.

\section{Standardization Table for Different Sugar Contents (Trail1)}

In the first trail, the sugar content is standardized by the following table.

\begin{tabular}{|l|c|c|c|c|c|}
\hline & $\mathbf{T}_{\mathbf{1}}$ & $\mathbf{T}_{\mathbf{2}}$ & $\mathbf{T}_{\mathbf{3}}$ & $\mathbf{T}_{\mathbf{4}}$ & $\mathbf{T}_{\mathbf{5}}$ \\
\hline PULP & $100 \mathrm{~g}$ & $100 \mathrm{~g}$ & $100 \mathrm{~g}$ & $100 \mathrm{~g}$ & $100 \mathrm{~g}$ \\
\hline SUGAR & $50 \%$ & $40 \%$ & $30 \%$ & $20 \%$ & - \\
\hline KMS & $2 \%$ & $2 \%$ & $2 \%$ & $2 \%$ & - \\
\hline
\end{tabular}

It is sensory evaluated in the form, and it gives the results with: $T_{2}$ as the first ranking followed by $T_{1 \&} T_{3}$.

Standardization of Sugar is Carried out by Further Taking the Samples of Different Sugar Contents

\begin{tabular}{|l|c|c|c|c|c|c|c|}
\hline & T1 & T2 & T3 & T4 & T5 & T6 & T7 \\
\hline PULP & $50 \mathrm{~g}$ & $50 \mathrm{~g}$ & $50 \mathrm{~g}$ & $50 \mathrm{~g}$ & $50 \mathrm{~g}$ & $50 \mathrm{~g}$ & $50 \mathrm{~g}$ \\
\hline SUGAR & $45 \%$ & $40 \%$ & $35 \%$ & $30 \%$ & $25 \%$ & $20 \%$ & - \\
\hline $\begin{array}{l}\text { CITRIC } \\
\text { ACID }\end{array}$ & $2 \%$ & $2 \%$ & $2 \%$ & $2 \%$ & $2 \%$ & $2 \%$ & - \\
\hline KMS & $2 \%$ & $2 \%$ & $2 \%$ & $2 \%$ & $2 \%$ & $2 \%$ & - \\
\hline
\end{tabular}

In this trail the uniform thickness, color change and the texture, are observed while drying.

Standardization of Sugar in the Third Trail

\begin{tabular}{|l|c|c|c|}
\hline & $\mathbf{T}_{\mathbf{1}}$ & $\mathbf{T}_{\mathbf{2}}$ & $\mathbf{T}_{\mathbf{3}}$ \\
\hline Pulp & $150 \mathrm{~g}$ & $150 \mathrm{~g}$ & $150 \mathrm{~g}$ \\
\hline Sugar & $10 \%$ & $25 \%$ & $30 \%$ \\
\hline Citric acid & $2 \%$ & $2 \%$ & $2 \%$ \\
\hline
\end{tabular}

$\mathrm{T}_{2}$ and $\mathrm{T}_{3}$ are the standardized points of the sugar levels

Standardization of the Citric Acid and Sugar in the Banana Bar

\begin{tabular}{|l|c|c|c|c|c|c|c|c|c|}
\hline SAMPLE & $\mathbf{T}_{\mathbf{1}}$ & $\mathbf{T}_{\mathbf{2}}$ & $\mathbf{T}_{\mathbf{3}}$ & $\mathbf{T}_{\mathbf{4}}$ & $\mathbf{T}_{\mathbf{5}}$ & $\mathbf{T}_{\mathbf{6}}$ & $\mathbf{T}_{\mathbf{7}}$ & $\mathbf{T}_{\mathbf{8}}$ & $\mathbf{T}_{\mathbf{9}}$ \\
\hline SUGAR & $10 \%$ & $10 \%$ & $10 \%$ & $25 \%$ & $25 \%$ & $25 \%$ & $30 \%$ & $30 \%$ & $30 \%$ \\
\hline PULP & $150 \mathrm{~g}$ & $150 \mathrm{~g}$ & $150 \mathrm{~g}$ & $150 \mathrm{~g}$ & $150 \mathrm{~g}$ & $150 \mathrm{~g}$ & $150 \mathrm{~g}$ & $150 \mathrm{~g}$ & $150 \mathrm{~g}$ \\
\hline $\begin{array}{l}\text { CITRIC } \\
\text { ACID }\end{array}$ & 0.5 & 1.0 & 1.5 & 0.5 & 1.0 & 1.5 & 0.5 & 1.0 & 1.5 \\
\hline KMS & $2 \%$ & $2 \%$ & $2 \%$ & $2 \%$ & $2 \%$ & $2 \%$ & $2 \%$ & $2 \%$ & $2 \%$ \\
\hline
\end{tabular}

It is sensory evaluated and $\mathrm{T}_{3} \& \mathrm{~T}_{4}$ are the most feasible and eligible type.

\section{Sensory Score for Different Banana Samples}

Mean Over All Acceptability of Samples 


\begin{tabular}{|l|c|}
\hline Samples & Over all Acceptability \\
\hline $\mathrm{T}_{1}$ & 3.76 \\
\hline $\mathrm{T}_{2}$ & 3.72 \\
\hline $\mathrm{T}_{3}$ & 4.02 \\
\hline $\mathrm{T}_{4}$ & 3.92 \\
\hline $\mathrm{T}_{5}$ & 3.8 \\
\hline $\mathrm{T}_{6}$ & 3.7 \\
\hline $\mathrm{T}_{7}$ & 2.8 \\
\hline
\end{tabular}

\section{RESULTS AND DISCUSSIONS}

Banana bar is prepared \& standardized at different levels, by standardizing the different ingredients. The appearance, color, texture, flavor, taste and the overall acceptability are tested and analyzed, by sensory evaluation. In the first trail of preparation, the levels of sugar are maintained as 50, 40, 30, 20 as $T_{1}, T_{2}, T_{3}, T_{4}$.

It is organoleptically tested with trained panel members and found that $\mathrm{T}_{2}$ sample first followed by $\mathrm{T}_{1}$ and $\mathrm{T}_{3}$, then again, the standardized sugar level is further tested by taking $T_{2} \& T_{3}$, as the medians. Then again $T_{1}-T_{7}$ variations of sugar, were made with a range of sugar content, from $\mathrm{T}_{1}=45,40,35,30,25,20$. It is organoleptically tested, and standardized the sugar content from a range of upto $30 \%$ and $35 \%$.

The remaining samples $\mathrm{T}_{4}, \mathrm{~T}_{5}$ and $\mathrm{T}_{6}$, should crystallize the sugar and their texture. Standardization of citric acid is also carried out, along with three different standard contents of sugars, like $10 \%, 25 \% \& 30 \%$ and taking citric acid as $1 \%, 1.5 \% \& 2 \%$. Organolepthic testing, by a 5 point hedonic scale is found that, samples $\mathrm{T}_{3} \& \mathrm{~T}_{2}$ are ideal in taste, texture and over all acceptability. The other samples are found to be crystallized and undergone through browning, for further studies. At various conditions, the difference in T.S.S content and ${ }^{\circ}$ brix, are checked.

\section{CONCLUSIONS}

Banana bar is an instant energy producing bar which provides a good mouth feel .It can be used as snack item .It has health benefits like decreasing blood pressure, soothes ulcer and also provides good energy value.

\section{REFERENCES}

1. 14 Banana Health Benefits You Might Not Know About, The Health Benefits of Banana Are Numerous By Chad Hagy, Published October 11, 2007.

2. 6 Awesome Health Benefits Of Bananas, By Golb On June 26, 2007 In Nutrition And Diet.

3. Prasad, K. et al. (2002) J. Trop. Agric. and Food Sci. 30: 83-88 December 15, 2007.

4. De Langhe, E., and P. de Maret. n.d. Tracking the banana: Significance to early agriculture. Coconutstudio.com. Retrieved December 15, 2007.

5. Denham, T. P., S. G. Haberle, C. Lentfer, R. Fullagar, J. Field, M. Therin, N. Porch, and B. Winsborough. 2003. Origins of agriculture at Kuk Swamp in the Highlands of New Guinea. Science (June 2003). Retrieved December 15, 2007.

6. Food and Agriculture Organization of the United Nations (FAO). 2004.

7. Kijoka Banana Fiber Cloth Association (KBFCA). n.d. Traditional crafts of Japan: Kijoka banana fiber cloth. Association for the Promotion of Traditional Craft Industries. Retrieved December 15, 2007.

8. Leibling, R. W., and D. Pepperdine. 2006. Natural remedies of Arabia. Saudi Aramco World 57(5): 14. 
9. Lejju, B. J., P. Robertshaw, and D. Taylor. 2006. Africa's earliest bananas?. Journal of Archaeological Science 33: 102-113. Retrieved December 15, 2007. 
